\title{
ICT Adoption and Economic Growth Nexus: Evidence from Leading African Economies
}

\author{
Adekunle Oluwole BINUYO*, Rafiu Adewale Aregbeshola \\ College of Economic and Management Sciences, University of South Africa \\ *binuya@unisa.ac.za
}

\begin{abstract}
This paper examines the impact of information and communication technology (ICT) on output growth in Nigeria, South Africa, Egypt, Algeria, Morocco, Libya, Sudan, Kenya, and Ghana. We use annual data on GDP (PPP) to proxy economic growth whilst internet users, mobile phone users, telephone users, personal computers users, and school enrolment (tertiary) covering from 1990 - 2013 were used to proxy ICT. The data were analysed in a dynamic panel environment using the 2SLS method. The robustness of the 2SLS result was confirmed by the GMM regression. The results imply a positive relationship between ICT and economic growth in accord with earlier studies. Few of the earlier studies investigate the causality aspect of the relationship and the few that did use ICT directly without resolving it into its sub-variables as done in this study. The Granger causality test results indicate that only fixed wireless communication system Granger cause GDPPPP out of the five predictors suggesting that the other ICT predictors merely associate with GDP not necessarily Granger cause it as most of the earlier studies erroneously suggest. The policy implication is that the affected countries should give policy priority to development of ICT infrastructure with specific emphasis on the fixed wireless communication system as precursors for ensuring sustainable growth in the medium and long - term.
\end{abstract}

Keywords: ICT, Economic Growth, Fixed wireless Communication, Global System of Mobile, Enrolment, Personal Computers, African Economies

\section{Introduction}

Experience in relation to growth has taken diverse direction across countries at different points in times. The growth experience has been that of revival and slump even among the developed countries. For example, during the 1990s the Japanese economy which has been praised by many in the 1980s suddenly became comatose while at the same time the US economy that has continued to show downward trend for over twenty years arising from the first oil shock of the 1980s became transformed into "a new economy" with high growth rates, reduced inflation rates, reduced unemployment rates, and reduced interest rates. This phenomenal occurrence led to a widening gap in the growth rates between the US and other developed countries during the 1990s. Consequently, the GDP per capita of OECD countries in 1982 was estimated to be $78 \%$ of that of the US but in 2000 , the figure dropped to $71 \%$. In view of this development, the growth rate of the US economy was comparatively faster than that of other developed countries in the 1990s. The source of the growing gap in growth rates of the US economy compared to that of other developed economies in the 1990s has been critically examined by researchers albeit without coming to a convergent point (Aghion and Howitt, 2006; Conway, De Rosa, Nicoletti and Steiner, 2006; Gust and Marquez, 2004; Nicoletti and Scarpetta, 2003). Further studies draw attention to ICT as the principal source of the widening growth gap between the US and other developed countries (Colecchia and Schreyer, 2001; Timmer, Ypma and van Ark, 2003).

These studies argue that unequal dissemination of ICT across various nations give rise to a digital divide which explains the observed variation in the growth rates across the various developed countries. This is because countries that are able to exploit economic opportunities provided by the new technology better than others are bound to grow faster than those countries that are unable to exploit the economic opportunities as much owing to the digital divide. By this rationale, countries such as America, Finland and Ireland who were able to take full advantage of the economic opportunities offered by the ICT in the 1990s were seen to show superior results in economic growth when compared with other developed countries. Contrariwise, the Nobel laureate economist, Solow (1987) once cited the infamous productivity paradox of the US economy wherein he purported that productivity stagnated despite increasing computing power. He 
posited consequently that increasing computing power does not guarantee productivity increase. Much of the early researches of the 1970s and 1980s also buttressed Solow's position on the productivity paradox. To refute the productivity paradox, recent studies in reviewing the paradox produce a wide range of explanations which include: mis-measurement of outputs and inputs and lags due to learning and adjustments as well as flaws in methodological frameworks and measurement errors. Further, the main benefits of using computer such as improved quality, timeliness, and customisation were not properly measured in official productivity statistics (Brynjolfsson, Malone, Gurbaxani and Kambil, 1994). Further, in disputing the productivity paradox, authors of recent studies have attributed the change in the direction of findings to improved data quality, and a new econometric framework that give rise to a more logical and credible empirical results (Lichtenberg, 1995; Diewert and Smith, 1994; Gurbaxani, Melville and Kraemer, 1998).

While several authors have noted positive evidence of returns from ICT at the firm and industry level, contrary is the case at the aggregate level wherein studies remain inconclusive as they have suffered from diverse limitations either methodologically as in the case of the study of Solow (1987) whose study suffered a mis-measurement of outputs and input amongst other limitations. The limitation of some others is analytical in the case of Pohjola (2002) who in his estimation did not cater for fixed and random effects of the data considering the time frame covered by his study as well as individual country peculiarity. In some others the limitation is with respect to inappropriate data which may arise as a result of variation in growth accounting techniques of specific countries giving rise to variations in estimations of individual country's data collection offices. Earlier studies have focussed extensively on researching into effect of ICT at the micro level (Brynjolfsson, Malone, Gurbaxani and Kambil, 1994; Quah, 2002; Stiroh, 2002; Jensen, 2007; O'Mahony and Vecchi, 2005). These studies have found a positive link between ICT adoption and productivity growth at the firm or industry level. Other studies investigating effect of ICT on growth at macro level has been targeted at developed countries (Jorgenson and Stiroh, 2000; Jorgenson, 2001; Oliner and Sichel, 2000 (for the US), Oulton, 2002 (for the UK), Jalava and Pohjola, 2002 (for Finland), Jorgenson and Motohashi, 2005 (for Japan), Colecchia and Schreyer (2001), Van Ark, Melka, Mulder, Timmer and Ypma (2002), Daveri (2002), and Timmer, Ypma, and Van Ark (2003) for EU economies; and Jorgenson (2003) for the G7 economies; Jorgenson and $\mathrm{Vu}$ (2007) for 110 countries.

These studies employ the growth accounting technique to estimate the contribution of ICT to economic growth. It should be noted however, that the reliability of the findings of such technique is good to the extent of the reliability of the data on which he analysis is based. This is a considerable challenge considering the variation in growth accounting technique estimation of contribution of ICT to economic growth across countries. Moreover, other studies which investigated the impact of ICT on economic growth include that of Waverman, Meschi and Fuss (2005) who investigate the impact of ICT on economic growth of 21 OECD countries over a period of twenty years $(1970$ - 1990) and reported a significant causal relationship between investment in telecommunication infrastructure and economic growth. Similarly, Jacobsen (2003) and Waverman, Meschi and Fuss (2005) both find a significant positive relationship between mobile phones usage and growth. In the same vein, Thompson and Garbacs (2007) in their analysis of panel data of 93 countries covering 1995 - 2003 find that penetration rates of telecommunication services improves growth. Further, Seo, Lee and Oh (2009) analysing panel data covering 29 countries in the 1990s show that investment in ICT has positive impact on GDP growth and not vice versa. In addition, Gruber and Koutroumpis (2010a) using panel data from 192 countries from 1990 - 2007 find significant contribution of mobile telecommunication on GDP growth. Also, Koutrompis (2009) in the application of Roller and Waverman model (2001) for investigation of ICT on growth in 22 OECD countries covering $2002-2007$ find that broadband penetration has a significant causal relationship with economic growth.

These studies although made use of cross country regression technique in their estimation. None of them employed the Granger-causality estimation to validate their findings. Further, while majority of the earlier studies focussed on developed countries, the few that are directed at developing countries are limited by scope of their coverage of the indicators of ICT indicators. Besides, none of the studies have come up with a model to explain the extent to which each of the ICT indicators contribute to growth. In view of the limitations of the earlier studies as outlined above, the study contributes methodologically to existing knowledge by resolving ICT into its sub-variables for the investigation; the analytical contribution of this study is in its 
catering for both fixed and random effects in the estimations as well as the investigation of causality and its direction amongst the study variables and sub-variables. The study made use of panel data of ten leading African economies covering from 1990 - 2015 sourced from the World Bank database.

\section{Literature Review}

Pursuant to the dictate of total factor productivity theory as well as the resource based view, the interest of researchers in investigating the relationship (if any) between ICT and growth both at the micro as well as the macro level has been heightened. UNDP (2001) in its development report attempt to qualify how technology especially ICT is enabling development effects. The report presented the association between technology and human development from the perspective that given that technological innovation enhances human capabilities - such as healthy lifestyle, knowledge, creativity, and participation in the social, economic, and political life of a community - and also impacts on economic growth through productivity gains. At the same time, human capabilities are an important means of achieving technological innovation. The report concluded that technology innovation and development are mutually reinforcing, creating a virtuous cycle. Abubakar and Tasmin (2012) in their investigation of the effect of ICT on performance of Nigerian banks using a panel data set spanning over 2001 to 2011 period obtained from the Nigerian Stock Exchange Fact book. The data was analysed using a combined techniques including the panel unit root (to affirm stationarity), panel cointegration to Fully Modified Ordinary Least Square and Generalised Method of Moments. The study finds a positive impact of ICT on banks performance.

Sanders (2007) in his study investigating the impact of e-business technologies on organizational performance argue that organizational collaboration, the foundation of supply chain management has been positively impacted by ICT. Meanwhile, organizational collaboration and information sharing in turn are expected to improve organizational performance. Thus the study proposes and tested a model of the relationship between organizational use of e-business technologies, organizational collaboration, and performance. The findings of the study reveal that use of e-business technologies impact performance both directly and indirectly by promoting both intra- and inter firm collaboration. At the macro level, recent studies have shown remarkable interest in the investigation of the capability of ICT to impact on economic growth. Many of these studies have been focussed on the developed countries perhaps due to relatively more readily available data. Khuong (2011) investigated ICT as a source of economic growth in the information age. The study highlights three channels through which ICT penetration can affect growth namely: fostering technology diffusion and innovation, enhancing the quality of decision making by firms and households, and also by increasing demand while keeping production costs minima. These three activities made possible by ICT adoption consequently culminate in increase in output level. The study made use of cross - sectional regression techniques to assess the effects of ICT on economic growth using a list of 102 countries across the globe. The paper investigates the causal link of ICT on growth using panel data of 102 countries obtained from World Development Indicator dataset for a ten year period from 1996 - 2005 during which ICT penetrate across countries.

Considering the number of countries involved, country fixed effect was introduced in the regression to remove country biasedness from the results obtained. This inclusion was found also to increase the $\mathrm{R}-$ squared significantly. The study finds that ICT penetration enhances growth with varied robustness of respective explanatory variables covered by the study. The study however ever failed to introduce impulse response analysis to estimate the effects of the shocks that the world economy suffered during the period covered by the study. The study also did not introduce random effect to address the variability of the sampled countries with respect to size, structure, and features peculiar to the respective countries covered. Moreover, the study also would have incorporated the Granger causality test to affirm its findings. Further, Pohjola (2001) applied an augmented version of the neo - classical growth model to infer the contribution of ICT to growth in a list of 39 countries covered by his study. He was however unable to find evidence for a positive contribution of ICT to growth in the 39 countries but was able to prove the association of ICT with growth in a smaller sample of 23 OECD countries from his study. Other studies also find inconclusive evidence on the growth effect of investment in ICT. Dewan and Kraemer (2000) in their analysis of panel data set of 36 countries covering 1985 - 1993 find that returns from IT are positive and significant for the developed countries in the sample but not statistically significant for the developing ones. 
Similarly, Jacobsen (2003), using data from 84 countries covering a ten year period from 1990 - 1999 find no significant growth effect arising from computer penetration although it confirm a significant positive link between mobile phones and growth in the countries covered by the study. These inconclusive findings coupled with observed limitations of the studies reviewed calls for further inquiry into the effect of ICT penetration on growth at the macro level particularly in the developing countries using more current dataset. Colecchia and Schreyer (2002) study investigates ICT investment and economic growth in nine OECD countries. The study compares the impact of information and communication technology (ICT) capital accumulation on output growth in Australia, Canada, Finland, France, Germany, Italy, Japan, the United Kingdom, and the United States over the period of $1980-2000$.

The study find that regardless of country differences, output growth in all the countries steadily grows though at different rates over the period covered by the study signalling to the fact that the United States has not been alone in the reaping of the benefits from the positive effects of ICT capital investment on economic growth nor was the United States the sole country to experience an acceleration of these effects.

The study argue that beyond increased or improved use of labour and capital, or through a rise in multi factor productivity, ICT has been found to be the new factor driving growth in several economies both at the micro or at the macro level. The major limitation of the study however is its failure to resolve ICT into its various components with a view to ascertaining the relative contribution of each of the identified components to overall growth. Leaning on the outcome of an intensive consultation process by the Partnership on Measuring ICT for Development held in Geneva in the year 2005, this study identify Personal Computers (PC), Global System of Mobile (GSM), Fixed wireless communication system, and Internet users as ICT basic core indicators. Other ICT indicators categorised as extended core are school enrolment and population share.

ICT penetration: The extent of ICT diffusion in each country is proxied by the penetration (per 100 inhabitants) of the indicators of measurement which are "personal computers", "mobile phones", "telephones", and "internet users". These are captured in the study as ICT_PC, ICT_MP, ICT_TP, and ICT_IU respectively.

Personal computers: Schreyer (2002) in his study investigating computer price indices and international growth and productivity comparisons argue that for several OECD countries where expenditure on computers is treated as a durable good for households or investment goods for organizations is found to culminate in GDP growth. Another study by Oulton (2002) adopting the growth accounting approach investigates the contribution of computer to both aggregate output as well as to aggregate input. The study reveals that on both counts, the contribution of ICT has been rising over time. This was further confirmed by the reduction in the growth rate of the UK compared to that of the US in the second half of 1990s owing to the reduction in the investment of UK in ICT compared to the US during that period.

Mobile phones: In their study of mobile phones and economic development in Africa, Mbiti and Acker (2010) noted that mobile phones subscription in Africa has increased from 16 million in the year 2000 to 376 million by the year $2008(2,250 \%$ increase!). Further, the study argue that mobile phones can contribute to growth in several ways which include: by improving access to and use of information at considerably reduced costs thereby improving coordination among agents and increasing market efficiency, improved firms' productive efficiency by improving their supply chain management, mobile phones create new jobs to address demand for mobile-related services thereby enhancing income generating opportunities both in rural as well as in urban areas, it reduces household risks by facilitating communication among social networks in response to shocks, it also facilitates delivery of financial, agricultural, health, and educational services. These findings were also corroborated by other similar studies (Muto and Yamano, 2009; Kloner and Nolen, 2010).

Fixed wireless communication system: The role of telephone in economic growth has attracted the interest of researchers over the years. Many previous studies in this regard were born out of curiosity as to if and how use of telephones has effect on economic growth. Hardy (1980) analysed data for 60 nations over the period of eight years (1968-1976) and find strong evidence indicative of significant contribution of telephones usage to economic development. In another study, Roller and Waverman (2001) using data on 21 OECD countries over a period of 20 years (1970-1990) find a significant and positive causal relationship between investment in telecommunication infrastructure and subsequent economic performance. A host of other similar studies further affirm the positive relationship between telecommunication and economic growth (Meschi and Fuss, 2005; Thompson and Garbacz, 2007; Gruber, and Koutroumpis, 2010; Koutroumpis, 2009). 
Internet usage: The issue of relationship between the internet and growth has been a subject of rigorous debate among researchers. There has been a considerable controversy over how and if the internet has any contribution to economic growth. Litan and Rivlin (2001) find that the internet improved management efficiency of the US firms by improving communication between the firms and their suppliers through an efficient supply chain management system. Further empirical studies suggest that internet usage lowers search costs which following search theory culminate in better performance and economic growth (Mbiti and Aker, 2010; Baye, Morgan and Scholten 2007; Aker, 2008).

School enrolment (tertiary): This is the gross tertiary enrolment rate. It is a reflection of the country's average quality of human capital which in turns determines the extent to which ICT can be exploited for maxima benefits. It was similarly used in a recent study by Vu (2011) that investigates ICT as a source of economic growth in the information age. Robinson and Crenshaw (2010) in their study analysing 74 countries from 1995 - 1999 came up with findings that suggest that development level, political freedom, and education were the most significant drivers of ICT adoption. Other studies also identified education (particularly tertiary) as a pedestal through which the potentials of ICT to influence economic growth can be harnessed. Seo, Lee, and Ho (2009) in their study aimed at answering the question: Does ICT investment widened the growth gap identify education as a necessity for enhancement of productivity. The authors argue that without adequate education and training, the exploitation of benefits of ICT for enhancement of productivity cannot be achieved. Further, Weber and Kauffman (2011) posit that education is one of the factors that influence ICT adoption. Arguably, ICT adoption is significantly influenced by education as the ability to learn and use ICT increases with education. Individuals with little or no education are generally challenged in their use of ICT when compared with those with appreciable level of education. The next variable to be discussed is t the GDP - the dependent variable of the study.

GDPPPP: The gross domestic product on the basis of purchasing power parity (GDP PPP) is the equivalent of the gross domestic product having been converted to international dollars using purchasing power parity rates and divided by the total population. The value of an international dollar is the purchasing power the dollar has over GDP as a US dollar has in the United States. PPPs can be expressed in the currency of either of the countries. The purpose is to determine the relative values of different currencies. This approach of GDP estimation will be used in this study for purposes of easy comparisons. Similar approach was adopted by Seo, Lee, and Oh (2009) in their study titled "Does ICT investment widen the growth gap?"

\section{Data and Methodology}

Data for the study were obtained from the Word Bank Data base of the African Development Indicators. The population of the study comprise of top ten economies in sub Saharan Africa in the context of their respective GDP which represents the market value of all final goods and services from each of the nations in a given year. This record based on the 2014 data from the World Economic Outlook by the International Monetary Fund is as computed in table 1 :

\begin{tabular}{lll}
\multicolumn{3}{l}{ Table 1: LIST OF TOP TEN AFRICAN ECONOMIES (G } \\
\hline S/N & CONTRY & GDP est (\$billions) \\
\hline 1 & Nigeria & 657.218 \\
2 & South Africa & 352.528 \\
3 & Egypt & 324.267 \\
4 & Algeria & 227.802 \\
5 & Angola & 131.407 \\
6 & Morocco & 112.552 \\
7 & Sudan & 70.030 \\
8 & Kenya & 62.722 \\
9 & Ethiopia & 49.857 \\
10 & Libya & 49.341 \\
\hline
\end{tabular}

Source: IMF World Economic Forum, 2013 
Data for the study covering from 1990 to 2013 were obtained from the 2014 data of the World Economic Outlook by the International Monetary Fund. Angola was however exempted from the analysis due to lack of ICT_PC data for the period. The data retrieved from the record comprises of GDP (PPP): This captures the totality of the gross domestic product converted to international dollars using purchasing power parity. ICT_PC: Which comprise of telecommunications, audio and video, computer and related equipment, electronic components, as well as other communication technology goods expressed as a percentage of total goods imports? ICT_IU: Refers to a measure of internet users - those people with access to the worldwide web. The estimate is per 100 people. ICT_MP: Is a measure of subscriptions to a public mobile telephone service that provides access to the PSTN using cellular technology expressed per 100 people. ICT_TP: Relates to the sum of active number of analogue fixed telephone lines. SCHENR: Captures the total enrolment in tertiary education regardless of age expressed as a percentage of the total population of the people having basic education.

Sample size and Sampling Technique: Since it is impracticable to include an entire study population in a research exercise (Asika, 2006), it becomes imperative to work with a sample drawn from the population. The study intends to work with nine African economies. The rationale for selecting the countries sampled for the study is underpinned partly due to the fact that they are the leading economies in Africa, and also considering that data for the study are available for these countries.

\section{Data Analyses}

The data was subjected to pre-estimation diagnostic tests to inform necessary treatment decisions. To verify the integration order of the series, the Levin, Lin, and Chu Panel Unit Root test is conducted. The test results (Tables 2-5) show that the variables are not integrated in the same order. All the variables became stationary after first differenced but two (ICT_IU\& ICT_MP) which became stationary after the second difference. This observation from the panel unit root test results informed the decision to adopt orthogonal deviation in the estimation to correct for these effects.

Table 2: DESCRIPTIVE STATISTICS

\begin{tabular}{lcccccc}
\hline & GDPPPP & ICT_IU & ICT_MP & ICT_PC & ICT_TP & SCHENR \\
\hline Mean & 7717.222 & 7.422924 & 29.37693 & 4.985384 & 5.081246 & 16.36864 \\
Median & 5237.969 & 1.017470 & 2.585972 & 4.125411 & 3.802297 & 12.19681 \\
Maximum & 30261.14 & 56.00000 & 180.4453 & 16.21698 & 20.33403 & 68.71934 \\
Minimum & 1859.918 & $2.30 \mathrm{E}-05$ & $6.71 \mathrm{E}-05$ & 1.038747 & 0.207664 & 0.698346 \\
Std. Dev. & 6660.527 & 12.17355 & 42.51956 & 2.369610 & 4.830178 & 15.66061 \\
Skewness & 1.556623 & 2.141276 & 1.460568 & 1.406694 & 0.816618 & 1.813667 \\
Kurtosis & 4.832612 & 7.189859 & 4.282590 & 5.410144 & 2.606011 & 5.974308 \\
Jarque-Bera & 117.4570 & 323.0566 & 91.60263 & 123.5156 & 25.40416 & 198.0366 \\
Probability & 0.000000 & 0.000000 & 0.000000 & 0.000000 & 0.000003 & 0.000000 \\
Sum & & & & & & \\
Sum Sq. Dev. & 1666920. & 1603.352 & 6345.417 & 1076.843 & 1097.549 & 3535.625 \\
& $9.54 \mathrm{E}+09$ & 31861.98 & 388701.2 & 1207.237 & 5016.084 & 52729.78 \\
Observations & 216 & & & & & \\
\hline
\end{tabular}

Source: Authors' computation

From the table 2 above, the descriptive statistics indicate that the data set exhibit some degree of asymmetry. The SD for example reveals that the data for ICT_PC is more clustered around the mean whilst that of GDPPPP widely dispersed from the mean. The Skewness which measures the symmetry of the data set indicates an appreciable symmetry in the data set. The nearer to zero the Skewness value is the more symmetrical is the data set. With the exception of ICT_TP, all the other study variables are leptokurtic. The highly significant pvalues however suggest some appreciable degree of conformance to the normality requirement. Thus presupposes applicability of rigorous analytical techniques. 
Table 3: PANEL UNIT ROOT TEST OF THE STUDY VARIABLES

\begin{tabular}{cllllll}
\hline VARIABLE & \multicolumn{4}{c}{ STATISTIC } & Prob. & DIFFERENCING \\
& L.L.\& C & I.P. \& S & ADF & PP & & \\
\hline GDPPPP & -3.91101 & -4.64993 & 71.9311 & 89.9072 & 0.000 & $1^{\text {st }}$ Difference \\
ICT_IU & -6.74538 & -9.62038 & 143.945 & 611.466 & 0.000 & $2^{\text {nd }}$ Difference \\
ICT_MP & -10.2463 & -10.7815 & 138.146 & 243.968 & 0.000 & $2^{\text {nd }}$ Difference \\
ICT_PC & -13.4976 & -12.6443 & 150.994 & 246.849 & 0.000 & $1^{\text {st }}$ Difference \\
ICT_TP & -3.69314 & -5.61452 & 69.8376 & 65.3895 & 0.000 & $1^{\text {st }}$ Difference \\
SCHENR & -9.20081 & -7.91668 & 89.5076 & 89.4764 & 0.000 & $1^{\text {st }}$ Difference \\
\hline
\end{tabular}

Source: Authors' computation

The panel unit root test conducted (using Levin, Lin, and Chu; ImPesaran and Shin W-stat; ADF Fisher Chisquare as well as PP techniques) on each of the study variable reveals that the data set is not stationary. Hence, has to be considered in the choice of analytical technique to be adopted for the data set.

The above table also reveals the order of integration of the study variables. The outputs of the differencing column indicate that the variables do not integrate at the same order. This needs to be considered in the choice of appropriate environment for the panel regression. Hence the adoption of two stage least square and panel GMM EGLS methods of regression. The above descriptive statistics as well as the pre-estimation diagnostic outcome informed the adoption of the 2STLS corroborated with the panel GMM EGLS regression techniques for the data analyses. The results are as reflected in tables 4 and 5.

Table 4: 2SLS PANEL REGRESSION (1990 - 2013) DEPENDENT VARIABLE GDPPPP

\begin{tabular}{llll}
\hline Variable & Coefficient & t-Statistic & Prob/ Std. Error \\
\hline ICT_IU & -75.862622 & -2.415987 & $(31.40026)^{* *}$ \\
ICT_MP & 2.673572 & 0.271610 & $(4.433101)$ \\
ICT_PC & 74.55008 & 1.278230 & $(58.32289)$ \\
ICT_TP & 219.7844 & 4.083499 & $(53.82257)^{* * *}$ \\
SCHENR & -22.24270 & -1.132985 & $(19.63194)$ \\
C & 6128.406 & 18.02794 & $(339.9394)^{* * *}$ \\
\hline
\end{tabular}

NB: Robust standard errors are in parentheses, $\mathrm{p}<0.01\left(^{* * *}\right), \mathrm{p}<0.05\left(^{* *}\right), \mathrm{p}<0.1\left(^{*}\right)$.

Table 5: PANEL GMM EGLS (Cross section random effects) Regression (1990 - 2013) Dependent Variable: GDPPPP

\begin{tabular}{llll}
\hline Variable & Coefficient & t-Statistic & Prob/ Std. Error \\
\hline ICT_IU & 46.46143 & 2.359576 & $(19.69058)^{* *}$ \\
ICT_MP & 6.395838 & 0.974486 & $(6.563296)$ \\
ICT_PC & 8.329344 & 0.124898 & $(66.68914)^{*}$ \\
ICT_TP & 158.5214 & 2.387457 & $(0.0180)^{* *}$ \\
SCHENR & 47.57530 & 2.169711 & $(21.92702)^{* *}$ \\
C & 5558.698 & 10.56585 & $(5261006)^{* * *}$ \\
\hline
\end{tabular}

NB: Robust standard errors are in parentheses, $\mathrm{p}<0.01\left(^{* * *}\right), \mathrm{p}<0.05\left(^{* *}\right), \mathrm{p}<0.1\left(^{*}\right)$.

The results obtained from the 2STLS were corroborated by those of the panel GMM EGLS (cross section random and period fixed effects). The results suggest that economic growth is significantly influenced by ICT_TP (fixed wireless phone), SCHENR (school enrolment), ICT_IU (internet users) and ICT_PC (personal computers) in that order with the highest level of influence coming from ICT_TP usage of fixed wireless communication system. These analyses were at the aggregate level (all sampled countries combined). For comparative purposes, each of the sampled countries was also subjected to same analyses and the results were as obtained hereunder. 
Table 6: COUNTRY SPECIFIC ANALYSES (ALGERIA)

\begin{tabular}{llll}
\hline Variable & Coefficient & t-Statistic & Prob/ Std. Error \\
\hline ICT_IU & 42.46654 & 0.476320 & $(89.15556)$ \\
ICT_MP & 11.06846 & 1.781450 & $(6.213177)^{*}$ \\
ICT_PC & 233.9915 & 5.845190 & $(40.03147)^{* * *}$ \\
ICT_TP & 90.33794 & 0.775221 & $(116.5318)$ \\
SCHENR & 56.71110 & 1.093820 & $(51.84684)$ \\
C & 7734.519 & 7.631525 & $(1013.496)^{* * *}$ \\
\hline Source: Authors' computation
\end{tabular}

Source: Authors' computation

Table 7: COUNTRY SPECIFIC ANALYSES (EGYPT)

\begin{tabular}{llll}
\hline Variable & Coefficient & t-Statistic & Prob/ Std. Error \\
\hline ICT_IU & -21.74778 & -3.676385 & $(5.915533)^{* * *}$ \\
ICT_MP & 33.65820 & 14.74142 & $(2.283240)^{* * *}$ \\
ICT_PC & -72.08326 & -1.211084 & $(0.2415)$ \\
ICT_TP & 117.8561 & 25.35494 & $(4.648249)^{* * *}$ \\
SCHENR & 57.57205 & 18.71173 & $(3.076790)^{* * *}$ \\
C & 5118.534 & 22.78813 & $(224.6141)^{* * *}$ \\
\hline
\end{tabular}

Source: Authors' computation

Table 8: COUNTRY SPECIFIC ANALYSES (GHANA)

\begin{tabular}{llll}
\hline Variable & Coefficient & t-Statistic & Prob/ Std. Error \\
\hline ICT_IU & 8.224966 & 0.610009 & $(13.48336)$ \\
ICT_MP & 5.726869 & 2.164147 & $(2.646248)^{* *}$ \\
ICT_PC & -61.62319 & -3.291226 & $(18.72348)^{* * *}$ \\
ICT_TP & 131.5307 & 2.593564 & $(50.71429)^{* *}$ \\
SCHENR & 89.24673 & 3.222817 & $(27.69215)^{* *}$ \\
C & 2012.320 & 39.50786 & $(50.93469)^{* * *}$ \\
\hline
\end{tabular}

Source: Authors' computation

Table 9: COUNTRY SPECIFIC ANALYSES (KENYA)

\begin{tabular}{llll}
\hline Variable & Coefficient & t-Statistic & Prob/ Std. Error \\
\hline ICT_IU & 2.869773 & 1.434058 & $(2.001156)$ \\
ICT_MP & 8.017545 & 6.265692 & $(1.279595)^{* * *}$ \\
ICT_PC & -13.56838 & -0.925682 & $(14.65771)$ \\
ICT_TP & -70.16934 & -2.399360 & $(29.24503)^{* *}$ \\
SCHENR & -74.42290 & -3.027311 & $(24.58383)^{* * *}$ \\
C & 2459.619 & 28.50542 & $(86.28601)^{* * *}$ \\
\hline
\end{tabular}

Source: Authors' computation

Table 10: COUNTRY SPECIFIC ANALYSES (LIBYA)

\begin{tabular}{llll}
\hline Variable & Coefficient & t-Statistic & Prob/ Std. Error \\
\hline ICT_IU & -580.4506 & -1.121519 & $(517.5573)$ \\
ICT_MP & 52.27645 & 1.426011 & $(36.65922)$ \\
ICT_PC & 3375.695 & 1.218536 & $(2770.288)$ \\
ICT_TP & 689.3608 & 2.186451 & $(315.2875)^{* *}$ \\
SCHENR & -213.1192 & -1.938082 & $(109.9640)^{*}$ \\
C & 13087.42 & 2.235226 & $(5855.079)^{* *}$ \\
\hline
\end{tabular}

Source: Authors' computation 
Table 11: COUNTRY SPECIFIC ANALYSES (MOROCCO)

\begin{tabular}{llll}
\hline Variable & Coefficient & t-Statistic & Prob/ Std. Error \\
\hline ICT_IU & -10.17636 & -0.865080 & $(11.76349)$ \\
ICT_MP & 33.27438 & 7.818805 & $(4.255687)^{* * *}$ \\
ICT_PC & 28.81513 & 0.728954 & $(39.52941)$ \\
ICT_TP & 13.91110 & 0.308885 & $(45.03653)$ \\
SCHENR & -121.6742 & -2.899028 & $(41.97069)^{*}$ \\
C & 5175.159 & 9.624343 & $(537.7156)^{* * *}$ \\
\hline
\end{tabular}

Source: Authors' computation

Table 12: COUNTRY SPECIFIC ANALYSES (NIGERIA)

\begin{tabular}{llll}
\hline Variable & Coefficient & t-Statistic & Prob/ Std. Error \\
\hline ICT_IU & -78.51666 & -1.761823 & $(44.56558)^{*}$ \\
ICT_MP & 65.83867 & 3.167069 & $(20.78851)^{* * *}$ \\
ICT_PC & -21.76634 & -1.030909 & $(21.11374)$ \\
ICT_TP & 228.6819 & 0.789520 & $(289.6468)$ \\
SCHENR & 59.34917 & 1.547808 & $(38.34402)$ \\
C & 2541.219 & 13.97392 & $(181.8543)^{* * *}$ \\
\hline
\end{tabular}

Source: Authors' computation

Table 13: COUNTRY SPECIFIC ANALYSES (SOUTH AFRICA)

\begin{tabular}{llll}
\hline Variable & Coefficient & t-Statistic & Prob/ Std. Error \\
\hline ICT_IU & -23.54781 & -7.174484 & $(3.282161)^{* * *}$ \\
ICT_MP & 28.32719 & 15.28939 & $(1.852735)^{* * *}$ \\
ICT_PC & -124.2492 & -3.708254 & $(33.50612)^{* * *}$ \\
ICT_TP & 79.32691 & 1.446442 & $(54.84278)$ \\
SCHENR & -42.16408 & -0.795659 & $(52.99262)$ \\
C & 10730.15 & 12.61502 & $(850.5854)^{* * *}$ \\
\hline
\end{tabular}

Source: Authors' computation

Table 14: COUNTRY SPECIFIC ANALYSES (SUDAN)

\begin{tabular}{llll}
\hline Variable & Coefficient & t-Statistic & Prob/ Std. Error \\
\hline ICT_IU & -10.14136 & -0.498714 & $(20.33500)$ \\
ICT_MP & 6.471888 & 1.217048 & $(5.317694)$ \\
ICT_PC & 18.85534 & 3.310714 & $(5.695250)^{* * *}$ \\
ICT_TP & -5.722765 & -0.175669 & $(32.57693)$ \\
SCHENR & 94.39230 & 7.604492 & $(12.41270)^{* * *}$ \\
C & 1674.458 & 28.00375 & $(59.79407)^{* * *}$ \\
\hline
\end{tabular}

Source: Authors' computation

From the results of the country specific analyses in the tables $6-14$, it is apparent that the effect of mobile phone is significant on economic growth at 0.01 levels for Egypt, Kenya, Morocco, Nigeria, and South Africa but significant at 0.05 and 0.1 levels for Ghana and Algeria respectively. The influence of personal computers on economic growth is significant at 0.01 levels for Algeria, Ghana, South Africa, and Sudan. The effect of internet on economic growth is significant at 0.01 levels for Egypt and South Africa but significant at 0.1 level for Nigeria. Fixed wireless phone usage effect on economic growth is significant at 0.05 levels for Ghana, Kenya, and Liberia but significant at 0.01 level for Egypt. We find the effect of school enrolment on economic growth to be significant at 0.01 for Egypt, Kenya, and Sudan whereas, it is significant at 0.05 level for Ghana and at 0.1 level for Liberia and Morocco. It is interesting to note from the results that school enrolment has a significant effect on economic growth for all the countries studied with the exception of Algeria, Nigeria, and South Africa. The five predictors of economic growth have varying levels of effect on the explained variable. The results suggest that different countries have to undertake proactive measures to revamp the various predictors of economic growth whose effect is either outright nil nor insignificant. This step will culminate in 
boosting the economic performance further for the respective countries. Finally, we proceed to the causality test between ICT indicators and economic growth. The Granger causality test results in table 15 reveal that only the fixed wireless communication system Granger cause GDPPPP. It is interesting to note that the causality of ICT_TP and GDPPPP is bidirectional at 1\% significance level. Apart from ICT_TP, no other ICT indicator Granger cause GDPPPP at 1\% (not even at $5 \%$ !). As can be supported by theory, the results also suggest that GDPPPP Granger cause school enrolment but not vice versa.

\section{Discussion}

This study finds that internet usage has a significant effect on economic growth. This aligns with the findings of Litan and Rivlin (2001) who find that internet usage improved management efficiency of the US firms by improving communication between firms and their suppliers through an efficient supply chain management and consequently boosting economic growth. Also, other similar studies support the argument that internet usage contribute to economic growth (Mbiti and Aker, 2010; ITU, 2009; Baye, Morgan, and Scholten, 2007; Aker, 2008). The finding that mobile phone usage also contribute to economic growth was buttressed by the findings of earlier researchers who find that mobile phone has a positive and significant influence on growth (Jacobsen, 2003; Waverman, Meschi, and Fuss, 2005; Garbacs, 2007). The contribution of mobile phone usage to economic growth can stem from different directions. Mobile phone is a potential source of income as it solves the problem of unemployment for some whose main business is rendering of mobile phone call services. This in its own way contributes to economic growth. Further, mobile phone usage has contributed immensely to reduction of search cost thereby making information available at a relatively cheaper rate for the information users. From theory, reduction in search cost translates to economic growth considering that it offers a form of cost reduction.

The significant influence of personal computers on growth agree with findings of other similar studies that support that personal computers do have a significant influence on growth. For instance, Jalave, and Phojola (2007) find a positive relationship between electricity and computer usage with economic growth of Finland. A similar study by Shahbaz and Rehman (2015) suggests the existence of a long run relationship between the variables of ICT, electricity consumption and growth and also that income growth increases electricity consumption in a non-linear relationship. Further, Dewan, and Kraemer (2000) affirm that returns from IT are positive and significant for the developed countries. The significant effect of telephone on economic growth correlate with findings of other studies maintaining that telephone has a significant effect on economic growth (Meschi, and Fuss, 2005; Thompson and Garbacz, 2007; Gruber, and Koutroumpis, 2010; Koutroumpis, 2009). On the issue of the positive and significant effect of school enrolment on growth, this result agrees with that of Robinson and Crenshaw (2010) and that of Weber and Kauffman (2011) who argue in favour of education as a driver of ICT adoption which in turn affect growth going by the efficiency labour theory which posit that technology adoption and diffusion has a great potential to enhance both efficiency and effectiveness of labour through diverse ways such as error reduction, increased speed of service delivery, etc.

The 2SLS and GMM results both establish the presence of a positive and significant relationship between the various explanatory variables with the explained variables. These tests however are not sufficient to suggest causality. This informed the decision to carry out the Granger causality test to reveal existence of causality and its direction with respect to the variables. The Granger causality test results indicate that only fixed wireless communication system Granger cause GDPPPP (at 1\% level) out of the five predictors suggesting that the other ICT predictors merely associate with GDP but not necessarily Granger cause it as most of the earlier studies erroneously suggest. The policy implication is that the affected countries should give policy priority to development of ICT infrastructure with specific emphasis on the fixed wireless communication system as precursors for ensuring sustainable growth in the medium and long - term.

\section{References}

Aghion, P. \& Howitt, P. (2006). Appropriate growth policy: A unifying framework. Journal of the European Association, 4, 269-314. 
Aker, J. C. \& Mbiti, I. M. (2010). Mobile phones and economic development in Africa. CGD Working Paper 211. Washington D.C. Centre for Global Development. http://www.cgdev.org/content/publications/detail/1424175

Aker, J. C. (2008). Does Digital Divide or Provide? The Impact of Mobile Phones on Grain Markets in Niger. BREAD Working Paper \# 177.

Asika, N. (2006). Research Methodology in Behavioral Sciences, First Edition. Ibadan: Longman Publishers Nig. Ltd.

Abubakar, A. \& Tasmin, R. B. H. (2012). The impact of information and communication technology on banks performance and customer service delivery in the banking industry. International Journal of Latest Trends in Finance and Economic Sciences, 2(1), 80 - 90.

Baye, M. R., Morgan, J. \& Scholten, P. (2007). Information, search and price dispersion. Handbook of Economics and Information System. North Holland: Elsevier.

Brynjolfsson, E., Malone, T. W., Gurbaxani, V. \& Kambil, A. (1994). Does information technology leads to smaller firms. Management Science, 40(12), 1628-1644.

Colecchia, A. \& Schreyer, P. (2001). ICT investment and economic growth in the 1990s: is the United States a unique case? A comparative study of nine OECD countries.STI Working Papers 2001/7, OECD, Paris.

Colecchia, A. \& Schreyer, P. (2002). ICT investment and economic growth in the 1990s: Is the United States a unique case? Review of Economic Dynamics, 5(1), 408 - 442

Conway, P., DeRosa, D., Nicoletti, G. \& Steiner, F. (2006). Regulation, competition and productivity convergence. OECD Economics Department Working Papers, 509.

Daveri, F. (2002).The new economy in Europe, 1992-2001. Oxford Review of Economic Policy, 18(3), 345-362.

Dewan, S. \& Kraemer, K. L. (2000). IT and productivity: evidence from country-level data. Management Science, 46(4), 548-562.

Diewert, W. E. \& Smith, A. M. (1994). Productivity measurement for a distribution firm, National Bureau of Economic Research, Working Paper No. 4812, July 1994.

Gruber, H. \& Koutroumpis, P. (2010a). Mobile telecommunications and the impact on economic development. Paper presented at the 52 $2^{\text {nd }}$ Economic Policy Panel Meeting, Einaudi Institute for Economics and Finance (EIEF), October22-23, Rome, Italy.

Gurbaxani, V., Melville, N. \& Kraemer, K. L. (1998).Disaggregating the return of investment to IT Capital, in: Proceedings of the International Conference on Information Systems, Helsinki, Finland.

Gust, C. \& Marquez, J. (2004). International comparison of productivity: The role of information technology and regulatory practices. Labor Economics, 11, 33 - 58.

Hardy, A. P. (1980).The role of the telephone in economic development. Telecommunications Policy, 4, 278286.

Jacobsen, K. F. L. (2003). Telecommunications-a means to economic growth in developing countries? Development Studies and Human Rights, Chr. Michelsen Institute, Bergen, Norway. Retrieved from /http://hdl.handle.net/10202/176S.

Jalava, J. \& Pohjola, M. (2002). Economic growth in the new economy: Evidence from advanced economies. Information Economics and Policy, 14(2), 189-210.

Jensen, R. (2007). The digital provide: Information (technology), market performance, and welfare in the South Indian fisheries sector. Quarterly Journal of Economics, 122, 879-924.

Jorgenson, D. W. \& Stiroh, K. J. (2000). Raising the speed limit: US economic growth in the information age. Economics Department Working Papers No. 261, OECD, Paris

Jorgenson, D. W. (2001). Information technology and the U.S. economy. American Economic Review, 91, 1-32.

Jorgenson, D. \& Motohashi, K. (2005). Information technology and the Japanese economy. Journal of the Japanese and International Economies, 19(4), 460-481.

Jorgenson, D. \& Vu, K. (2007). Information technology and the world growth resurgence. German Economic Review, 8(2), 125-145.

Jorgenson, D. (2003). Information technology and the G7 economies. World Economics, 4(4), 139-169.

Koutroumpis, P. (2009). The economic impact of broad band on growth: A simultaneous approach. Telecommunications Policy, 33, 471-485.

Khuong, M. V. (2011). ICT as a source of economic growth in the information age. Telecommunications Policy, $35(4), 357-372$. 
Kloner, S. \& Nolen, P. J. (2010). Cell phones and rural labor markets: Evidence from South Africa. Proceedings of the German Development Economic Conference, Hannover 201056, [Online] Available: http;//hdl.handle.net/10419/39968. (Accessed 10 March 2015)

Lichtenberg, F. R. (1995). The output contributions of computer equipment and personal: a firm-level analysis. Economics of Innovation and New Technology, 3, 201-217.

Litan, R. E. \& Rivlin, A. M. (2001). Projecting the economic impact of the internet. The American Economic Review, 91(2), $313-317$

Meschi, M. \& Fuss, M. (2005). The impact of telecoms on economic growth in developing countries. The Vodafone Policy Paper Series

Muto, M. \& Takashi, Y. (2009). The Impact of Mobile Phone Coverage Expansion on Market Participation: Panel Data Evidence from Uganda World Development.

Nicoletti, G. \& Scarpetta, S. (2003). Regulation, productivity and growth: OECD evidence. Economic Policy, 18, 9-72.

O'Mahony, M. \& Vecchi, M. (2005). Quantifying the impact of ICT capital on output growth: A heterogeneous dynamic panel approach. Economica, 72, 615-633.

Oliner, S. \& Sichel, D. (2000). The resurgence of growth in the late 1990s: Is information technology the story? Journal of Economic Perspectives, 14(4), 3-22.

Oulton, N. (2002). ICT and productivity growth in the United Kingdom. Oxford Review of Economic Policy, $18(3), 363-379$

Pohjola, M. (2001). Information technology and economic growth: Across - country analysis. In M. Pohjola (Ed.), Information technology and economic development. Oxford: Oxford University Press.

Pohjola, M. (2002).The new economy in growth and development. Oxford Review of Economic Policy, 18(3), 380-396.

Quah, D. (2002). Technology dissemination and economic growth: Some lessons for the new economy. In C.E. Bai, \& C.W. Yuen (Eds.), Technology and the new economy (pp. 95-156). Cambridge, MA: MIT Press.

Robinson, K. K. \& Crenshaw, E. M. (2010). Reevaluating the global digital divide: Socio-Demographic and conflict barriers to the internet revolution. Sociological Inquiry, 80(1), 34 - 62

Roller, L. H. \& Waverman, L. (2001). Telecommunications infrastructure and economic development, a simultaneous equations approach. American Economic Review, 91(4), 909-923.

Sanders, N. R. (2007). An empirical study of the impact of e-business technologies on organizational collaboration and performance. Journal of Operation Management, 25(6), 1332 - 1347

Schreyer, P. (2002). Computer Price Indices and International Growth Comparisons. Review of Income and Wealth, forthcoming.

Seo, H. J., Lee, Y. S. \& Oh, J. H. (2009). Does ICT investment widen the growth gap? Telecommunications Policy, $33,422-431$.

Shahbaz, M. \& Rehman, I. U. (2015). The role o information communication technology and economic growth in recent electricity demand: Fresh evidence from combine cointegration approach in UAE. Springer Science Business Media, New York.

Solow, R. M. (1987). We'd better watch out, New York Times Book Review, July 12, p. 36.

Stiroh, K. (2002). Are spill overs driving the new economy? Review of Income and Wealth, 48(1), 33-58.

Thompson, H. G. Jr. \& Garbacz, C. (2007). Mobile, fixed line and Internet service effects on global productive efficiency. Information Economics and Policy, 19(2), 189-214.

Timmer, M., Ypma, G. \& Van Ark, B. (2003). IT in the European Union, driving productivity divergence? Research Memorandum GD-67, Groningen Growth and Development Centre. Retrieved from /http://www.ggdc.net/publications/memorandum/gd67.pdfS.

Van Ark, B., Melka, J., Mulder, N. Timmer, M. \& Ypma, G. (2003). ICT investment and growth accounts for the European Union.

$\mathrm{Vu}, \mathrm{K}$. M. (2011). ICT as a source of economic growth in the information age: Empirical evidence from the 1996 - 2005 period.

Waverman, L., Meschi, M. \& Fuss, M. (2005). The impact of telecoms on economic growth in developing countries. Africa: The impact of mobile phones. The Vodafone Policy Paper Series, 2, 10-24.

Weber, D. M. \& Kauffman, R. J. (2011). What drives global ICT adoption? Analysis and research directions. Electronic Commerce Research Applications, 10(1), 683-701. 